\title{
Association between inflammatory extension and the ventricular size in adult chronic communicating hydrocephalus: An experimental model of adult hydrocephalus
}

\author{
Ignacio Jusue-Torres ${ }^{1 *}$, Jennifer Lu', Eric W Sankey ${ }^{1}$, Tito Vivas-Buitrago ${ }^{1}$, Joshua Crawford ${ }^{2}$, Mikhail Pletnikov², \\ Jiadi Xu' ${ }^{3}$, Ari Blitz ${ }^{4}$, Barbara Crain ${ }^{5}$, Alicia Hulbert ${ }^{6}$, Hugo Guerrero-Cazares', Oscar Gonzalez-Perez \\ Alfredo Quiñones-Hinojosa', Pat McAllister ${ }^{8}$, Daniele Rigamonti ${ }^{1}$
}

From Hydrocephalus 2015

Banff, Canada. 18-21 September 2015

\section{Introduction}

The pathogenesis of normal pressure hydrocephalus $(\mathrm{NPH})$ is not fully understood and the relationship between inflammatory reaction extension and the ventricular enlargement is unknown.

\section{Methods}

Bilateral subarachnoidal injection of kaolin was administered in the cranial convexities of 20 adult rats. MRI was obtained using a Bruker Biospec 11.7 T MRI scanner at 14, 60, 90 and 120 days post kaolin injection. Radiological kaolin extension was defined by the number of kaolin locations showed in the MRI studies. At the end of the experiment, the heads of the rats were decalcified and sliced along with the skull in order to preserve the meninges and bone. A blinded neuropathologist studied the anatomical preparations and analyzed kaolin extension and the inflammatory and fibrotic response.

\section{Results}

Radiological ventricular size showed progressive growth over time at all times $(\mathrm{p}<0.0001)$. The fastest ventricular enlargement happened within the first 2 months. Pathological specimens revealed kaolin location at the subarachnoidal space. The extension of the kaolin migration was heterogeneous among rats. Inflammatory and fibrotic response was present at the cranial convexities in all rats, adjacent to superior sagittal sinus in $94 \%$ rats, at the interhemispheric fissure in $56 \%$ rats, at the Olfactory Bulb in $61 \%$ rats, at the anterior basal cisterns in $72 \%$ rats, supracerebellar in $56 \%$ rats, at the quadrigeminal cisterns in $61 \%$ rats, at the lateral midbrain cisterns in $50 \%$ rats and within the Virchow-Robin spaces in $61 \%$ rats. The extension of the inflammatory response in the subarachnoidal space was associated with ventricular size $(\mathrm{p}=0.02)$, and the rate of ventricular enlargement $(\mathrm{p}=0.03)$.

\section{Conclusions}

The extension of the inflammatory response to kaolin injected in the subarachnoidal space is associated with ventricular size and the rate of ventricular enlargement in adult rats.

\footnotetext{
Authors' details

'Johns Hopkins University. School of Medicine, Department of Neurosurgery. USA. ${ }^{2}$ Johns Hopkins University, School of Medicine, Department of Psychiatry and Behavioral Sciences, USA. ${ }^{3}$ Johns Hopkins University, School of Medicine, F. M. Kirby Research Center for Functional Brain Imaging at the Kennedy Krieger Institute, USA. ${ }^{4}$ Johns Hopkins University, School of Medicine, Department of Radiology and Radiological Science, USA. Johns Hopkins University, School of Medicine, Department of Pathology, Division of Neuropathology, USA. ${ }^{6} J o h n s$ Hopkins University, School of Medicine, Department of Oncology, USA. ${ }^{7}$ University of Colima, Facultad de Psicologia, Laboratory of Neuroscience, Mexico. ${ }^{8}$ Washington University, School of Medicine in St Louis, Department of Neurosurgery, USA.
}

\footnotetext{
* Correspondence: jusuet1@jhmi.edu

'Johns Hopkins University. School of Medicine, Department of Neurosurgery. USA

Full list of author information is available at the end of the article
} 


\section{References}

1. Sankey EW, Jusue-Torres I, Elder BD, et al: Functional gait outcomes for idiopathic normal pressure hydrocephalus after primary endoscopic third ventriculostomy. J Clin Neurosci 2015, 1-6.

2. Moran D, Kosztowski TA, Jusue-Torres I, et al: Does CT wand guidance improve shunt placement in patients with hydrocephalus? Clin Neurol Neurosurg 2015, 132:26-30.

3. Jusue Torres I, Hoffberger JB, Rigamonti D: Complications Specific to Lumboperitoneal Shunt. Complications of CSF Shunting in Hydrocephalus. Springer; 2015, 203-11.

4. Elder BD, Sankey EW, Goodwin CR, Jusue-Torres I, Khattab MH, Rigamonti D: Outcomes and Experience with Lumbopleural Shunts in the Management of Idiopathic Intracranial Hypertension. World Neurosurg 2015, 1-6.

5. Jusué-Torres I, Hoffberger JB, Rigamonti D: Complications of Lumboperitoneal Shunts for Idiopathic Intracranial Hypertension. Cureus 2014.

6. Jusue Torres I, Hoffberger JB, Rigamonti D: Complications of Lumboperitoneal Shunts for Normal Pressure Hydrocephalus. Cureus 2014

7. Elder $\mathrm{BD}$, Bankah $\mathrm{P}, \mathrm{Blitz} \mathrm{AM}$, et al: Core imaging in adult hydrocephalus. Adult Hydrocephalus: Cambridge University Press;Rigamonti D 2014:110-20.

doi:10.1186/2045-8118-12-S1-057

Cite this article as: Jusue-Torres et al: Association between inflammatory extension and the ventricular size in adult chronic communicating

hydrocephalus: An experimental model of adult hydrocephalus. Fluids and Barriers of the CNS 2015 12(Suppl 1):057.

\section{Submit your next manuscript to BioMed Central and take full advantage of:}

- Convenient online submission

- Thorough peer review

- No space constraints or color figure charges

- Immediate publication on acceptance

- Inclusion in PubMed, CAS, Scopus and Google Scholar

- Research which is freely available for redistribution

Submit your manuscript at www.biomedcentral.com/submit 